Jurnal Keperawatan Silampari

Volume 5, Nomor 1, Desember 2021

e-ISSN: 2581-1975

p-ISSN: 2597-7482

DOI: https://doi.org/10.31539/jks.v5i1.2833

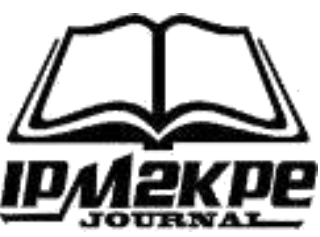

\title{
PERBEDAAN KUALITAS HIDUP PASIEN COVID-19 DENGAN COMORBID
}

\author{
Linda Widiastuti \\ Sekolah Tinggi Ilmu Kesehatan Hang Tuah Tanjungpinang \\ lindawidiastuti078@gmail.com
}

\begin{abstract}
ABSTRAK
Penelitian ini bertujuan untuk mengetahui perbedaan kualitas hidup pasien COVID-19 dengan comorbid di wilayah Kota Tanjungpinang. Metode penelitian menggunakan penelitian analitik dengan design komparatif. Hasil penelitian mayoritas responden COVID-19 dengan comorbid DM: rentang usia 56-65 tahun 26 (50\%), jenis kelamin perempuan $38(73,1 \%)$, pendidikan SMA 26 (50\%), tanda gejala COVID-19 (demam, batuk, sakit tenggorokan dan sesak nafas) $52(100 \%)$. Sedangakan mayoritas responden COVID-19 dengan comorbid HT: rentang usia 56-65 tahun 21 (26,9\%), jenis kelamin perempuan 27 (51,9\%), pendidikan SMA 23 (44,2\%), tanda gejala COVID-19 (demam, sakit kepala) $52(100 \%)$, pemeriksaan gula darah sewaktu tidak normal dengan jumlah 43 orang $(82,7 \%)$. pemeriksaan tekanan darah hipertensi stadium $2((\geq 140 />90 \mathrm{mmHg})$ dengan jumlah 26 orang (50\%). Hasil analisis bivariat uji mann whitney test menunjukkan bahwa $\rho$ Value sebesar $0,001(<0,05)$. Simpulan, ada perbedaan kualitas hidup pasien COVID-19 dengan comorbid diabetes melitus dan hipertensi.
\end{abstract}

Kata Kunci: COVID-19, Diabetes Melitus, Hipertensi, Kualitas Hidup

\section{ABSTRACT}

This study aims to determine the difference in the quality of life of COVID-19 patients with Comorbid in the Tanjungpinang City area. The research method uses analytical research with a comparative design. The results of the study were the majority of COVID-19 respondents with comorbid DM: age range 56-65 years 26 (50\%), female sex 38 (73.1\%), high school education 26 (50\%), signs of COVID-19 symptoms (fever, cough, sore throat and shortness of breath) 52 (100\%). While the majority of COVID19 respondents with comorbid HT: age range 56-65 years 21 (26.9\%), female sex 27 (51.9\%), high school education 23 (44.2\%), signs of COVID-19 symptoms (fever, headache) 52 (100\%), blood sugar examination when abnormal with 43 people $(82.7 \%)$. Blood pressure examination of stage 2 hypertension $(\geq 140 />90 \mathrm{mmHg}$ ) with a total of 26 people (50\%). The results of the bivariate analysis of the Mann Whitney test showed that the Value was 0.001 (<0.05). In conclusion, there was a difference in the quality of life. COVID-19 patients with comorbid diabetes mellitus and hypertension.

Keywords: COVID-19, Diabetes Mellitus, Hypertension, Quality of Life 


\section{PENDAHULUAN}

Penyakit Coronavirus 2019 (corona virus disease 2019/COVID-19) merupakan penyakit infeksi baru yang disebabkan oleh Severe Acute Respiratory Syndrome Coronavirus-2 (SARS-CoV-2) (WHO, 2019). WHO (2020) menetapkan wabah COVID-19 sebagai Public Health Emergency of International Concern (PHEIC) pada tanggal 30 Januari 2020, namun kasus ini semakin menyebar secara cepat hingga WHO menetapkan COVID-19 sebagai pandemi pada tanggal 11 Maret 2020 (WHO, 2020).

WHO pada tanggal 30 Januari 2020 sampai dengan tanggal 12 April 2021, COVID19 sudah menginfeksi 137 juta penduduk diseluruh dunia dengan jumlah penduduk yang meninggal sebanyak 2,94 juta. Penyakit ini pertama kali ditemukan di Wuhan, Cina pada tahun 2019 yang kemudian menyebar hingga ke 216 negara (WHO, 2021). Hingga tanggal 12 April 2021, terdapat 1,57 juta kasus terkonfirmasi positif COVID-19 dan terdapat 42.656 kasus yang berujung kematian. Data COVID-19 di Kepulauan Riau sebanyak 9.303 kasus dengan angka kematian 230 kasus. Kota Tanjungpinang sebagai urutan ke dua di provinsi Kepulauan Riau dengan data COVID-19 sebanyak 1591 kasus dengan angka kematian 31 kasus (KPCPEN, 2020).

Virus SARS-CoV-2 menyebar secara dominan melalui droplet respiratorik yang dihasilkan saat bersin atau batuk, dan dapat juga secara tidak langsung melalui objek atau permukaan yang terkontaminasi (Andri et al., 2021; Padila et al., 2021). Transmisi dapat terjadi dari pasien simtomatik maupun asimtomatik. Masa inkubasi COVID-19 sekitar 2-14 hari (rerata 5 hari). Pasien COVID-19 mengalami gejala utama demam, batuk, dan sesak napas. Gejala lain dapat berupa mialgia, anoreksia, malaise, nyeri menelan, mual/muntah, kongesti nasal, sakit kepala, dan diare. Pada kasus berat pasien dapat mengalami pneumonia berat, Acute Respiratory Distress Syndrome (ARDS), sepsis, syok sepsis, dan Multiple Organ Dysfunction Syndrome (MODS) (Willim et al., 2020).

COVID-19 lebih berisiko bagi orang yang sebelumnya mengidap penyakit (dalam istilah medis disebut komorbid). Manifestasi klinis COVID-19 yang ditemukan sangat beragam, begitu juga dengan faktor komorbid yang menyertainya. Pada saat masuk rumah sakit di China, 20-51\% pasien dilaporkan mempunyai setidaknya salah satu komorbid diantara diabetes melitus (10-20\%), hipertensi (10-15\%), dan penyakit jantung dan pembuluh darah lainnya (7-40\%) (Guan et al., 2020; Padila et al., 2021). Menurut Guan et al., (2020) bahwa adanya salah satu komorbid akan meningkatkan risiko sebesar 3,4 kali lipat untuk terkena Acute Respiratory Distress Syndrome (ARDS). Serupa dengan influenza, SARS-CoV, dan MERS-CoV, COVID-19 lebih cenderung menyebabkan gagal napas dan kematian pada kelompok pasien komorbid.

Berdasarkan data Satuan Tugas Penanganan COVID-19 per tanggal 13 Oktober 2020, dari total kasus yang terkonfirmasi positif COVID-19, sebanyak 1.488 pasien tercatat memiliki penyakit penyerta. Presentase komorbid terbanyak diantaranya penyakit hipertensi sebesar 50,5\%, kemudian diikuti diabetes melitus 34,5\% dan penyakit jantung 19,6\%. Sementara dari jumlah 1.488 kasus pasien meninggal diketahui 13,2\% dengan hipertensi, 11,6\% dengan diabetes melitus serta 7,7\% dengan penyakit jantung (Kemenkes, 2020).

Penyakit komorbid hipertensi dapat memperparah prognosis COVID-19 disebabkan karena konsumsi obat ACE inhibitor dan ARB sebagai intervensi obat hipertensi ternyata dapat memperparah COVID-19. Virus ini akan mengikat Angiotensin converting enzyme 2 (ACE2) yang ada di paru kemudian penetrasi ke dalam sel (Tignanelli et al., 2020).

Berdasarkan hasil penelitian Ping et al., (2020) menyatakan bahwa responden dengan tiga atau lebih penyakit kronis memiliki kualitas hidup yang lebih rendah dibandingkan responden lainnya. Penelitian lainnya dilakukan oleh Schwartz \& Oppold (2021) dimana 
dari 279 partisipan diperoleh hasil bahwa orang yang menjalani karantina memiliki kualitas kesehatan secara umum yang buruk terutama orang dengan penyakit kronis. Hal ini disebabkan sistem kekebalan tubuh yang sudah melemah dan adanya kerusakan organ akibat penyakit kronis yang tentunya akan mempengaruhi kualitas hidup pasien. Penelitianpenelitian sebelumnya membahas tentang COVID-19 secara umum. Penelitian ini membahas lebih spesifik perbedaan kualitas hidup pasien COVID-19 dengan comorbid.

\section{METODE PENELITIAN}

Penelitian menggunakan quasi eksperiment pre-post test design. Analisis bivariat menggunakan uji spearman correlation karena skala data pasien COVID-19 dengan comorbid hipertensi dan diabetes melitus memiliki skala data ordinal. Dan Uji Mann Whitney Test pada dua kelompok tidak berpasangan, digunakan untuk melihat perbedaan antara dua variabel yaitu perbedaan kualitas hidup pasien COVID-19 dengan comorbid diabetes dan melitus hipertensi.

Tehnik sampling yang digunakan total sampling sebanyak 104 responden. Data diolah menggunakan program computer. Kaji etik dalam penelitian ini dilakukan oleh Komite Etik Penelitian Kesehatan (KEPK) Sekolah Tinggi Ilmu Kesehatan Hang Tuah Tanjungpinang.

\section{HASIL PENELITIAN}

Tabel. 1

Distribusi Karakteristik Responden

\begin{tabular}{lcccc}
\hline \multicolumn{1}{c}{$\begin{array}{c}\text { Karakteristik Responden } \\
\text { COVID-19 }\end{array}$} & \multicolumn{2}{c}{ Comorbid } & \multicolumn{2}{c}{ Comorbid } \\
& Diabetes Melitus (DM) & Hipertensi (HT) \\
\cline { 2 - 5 } & $\mathrm{n}$ & $\%$ & $\mathrm{n}$ & $\%$ \\
\hline Usia & 14 & 40,4 & 19 & 36,5 \\
$46-55$ & 21 & 26,9 & 26 & 50,0 \\
$56-65$ & 17 & 32,7 & 7 & 13,5 \\
$>65$ & & & & \\
Jenis kelamin & 25 & 48,1 & 14 & 26,9 \\
Laki-Laki & 27 & 51,9 & 38 & 73,1 \\
Perempuan & & & & \\
Pendidikan & 8 & 15,4 & 4 & 7,7 \\
SD & 11 & 21,2 & 13 & 25,0 \\
SMP & 23 & 44,2 & 26 & 50,0 \\
SMA & 10 & 19,2 & 9 & 17,3 \\
D3/S1/S2 & & & & \\
Tanda Gejala COVID-19 & 52 & 100,0 & 52 & 100,0 \\
Demam & 52 & 100,0 & 49 & 94,2 \\
Batuk & 45 & 86,5 & 39 & 75,0 \\
Pilek & 52 & 100,0 & 50 & 96,2 \\
Sakit Tenggorokan & 45 & 86,5 & 52 & 100,0 \\
Sakit Kepala & 52 & 100,0 & 49 & 94,2 \\
Sesak Nafas & 33 & 63,5 & 47 & 90,4 \\
Lemah & 40 & 76,9 & 36 & 69,2 \\
Nyeri Otot & 49 & 94,2 & 48 & 92,3 \\
Mual Muntah & 42 & 80,8 & 46 & 88,5 \\
Nyeri Abdomen & 52 & 100 & 52 & 100 \\
\hline TOTAL & & & &
\end{tabular}


Berdasarkan tabel 1 diketahui karakteristik mayoritas responden COVID-19 dengan comorbid DM: rentang usia 56-65 tahun 26 (50\%), jenis kelamin perempuan 38 (73,1\%), pendidikan SMA 26 (50\%), tanda gejala COVID-19 (demam, batuk, sakit tenggorokan dan sesak nafas) $52(100 \%)$. Sedangakan mayoritas responden COVID19 dengan comorbid HT: rentang usia 56-65 tahun 21 (26,9\%), jenis kelamin perempuan $27(51,9 \%)$, pendidikan SMA 23 (44,2\%), tanda gejala COVID-19 (demam, sakit kepala) 52 (100\%).

Tabel. 2

Distribusi Frekuensi Gula Darah Sewaktu

Responden di ruang COVID-19

\begin{tabular}{lcc}
\hline \multicolumn{1}{c}{ Gula Darah Sewaktu } & \multicolumn{2}{c}{ Distribusi Frekuensi } \\
\cline { 2 - 3 } & $\mathrm{n}$ & $(\%)$ \\
\hline Normal 100-140 & 9 & 17,3 \\
Tidak Normal $<100,>140$ & 43 & 82,7 \\
\hline Jumlah & 52 & 100 \\
\hline
\end{tabular}

Berdasarkan tabel 2 menunjukkan bahwa mayoritas responden hasil pemeriksaan gula darah sewaktu tidak normal dengan jumlah 43 orang $(82,7 \%)$.

Tabel. 3

Distribusi Frekuensi Tekanan Darah Responden di ruang COVID-19

\begin{tabular}{lcc}
\hline \multicolumn{1}{c}{ Tekanan Darah } & \multicolumn{2}{c}{ Distribusi Frekuensi } \\
\cline { 2 - 3 } & $\mathrm{n}$ & $(\%)$ \\
\hline Hipotensi $(>110 />70 \mathrm{mmHg})$ & 6 & 11,5 \\
Prehipertensi $(120-129 / 80 \mathrm{mmHg})$ & 3 & 5,8 \\
Hipertensi stadium 1 $(130-139 / 80-89 \mathrm{mmHg})$ & 17 & 32,7 \\
Hipertensi stadium 2 $(\geq 140 />90 \mathrm{mmHg})$ & 26 & 50,0 \\
\hline \multicolumn{1}{c}{ Jumlah } & 52 & 100 \\
\hline
\end{tabular}

Berdasarkan tabel 3 menunjukkan bahwa mayoritas responden hasil pemeriksaan tekanan darah hipertensi stadium $2((\geq 140 />90 \mathrm{mmHg})$ dengan jumlah 26 orang $(50 \%)$.

Tabel. 4

Hubungan kualitas hidup pasien COVID-19 dengan comorbid Diabetes Melitus dan Hipertensi di ruang COVID-19

\begin{tabular}{ccc}
\hline \multirow{2}{*}{ Variabel } & \multicolumn{2}{c}{ Comorbid } \\
& Diabetes Melitus dan Hipertensi & \\
\cline { 2 - 3 } & Kekuatan korelasi secara statistik & $\rho$ Value \\
\hline Kualitas Hidup & $-0,707$ & 0,000 \\
\hline
\end{tabular}

Berdasarkan tabel 4 menunjukkan bahwa hasil penelitian ada hubungan yang signifikan pasien COVID-19 dengan comorbid diabetes melitus dan hipertensi terhadap kualitas hidup dengan hasil uji statistik $\rho$ Value sebesar $0,000(<0,05)$ dan kekuatan korelasi secara statistik -0,707 yakni terdapat korelasi negatif, yang memiliki makna, bahwa pasien COVID-19 dengan comorbid DM dan HT akan memberikan pengaruh yang kuat terhadap kualitas hidup. 
Tabel. 5

Perbedaan Kualitas Hidup pasien COVID-19 dengan

Comorbid Diabetes Melitus dan Hipertensi di COVID-19

\begin{tabular}{|c|c|c|c|c|c|}
\hline \multirow{3}{*}{$\begin{array}{c}\text { Variabel } \\
\text { Comorbid }\end{array}$} & \multicolumn{4}{|c|}{ Kualitas Hidup } & $\rho$ Value \\
\hline & \multicolumn{2}{|c|}{ Baik } & \multicolumn{2}{|c|}{ Buruk } & \multirow{4}{*}{0,001} \\
\hline & $n$ & $\%$ & $n$ & $\%$ & \\
\hline Diabetes Melitus & 19 & 36,5 & 33 & 63,5 & \\
\hline Hipertensi & 27 & 51,9 & 25 & 48,1 & \\
\hline Total & 52 & 100 & 52 & 100 & \\
\hline
\end{tabular}

Berdasarkan tabel 5 menunjukkan bahwa hasil penelitian ada perbedaan yang signifikan kualitas hidup pasien COVID-19 dengan comorbid diabetes melitus dan hipertensi dengan hasil uji statistik $\rho$ Value sebesar $0,001(<0,05)$.

\section{PEMBAHASAN}

Hasil penelitian menunjukkan ada perbedaan yang signifikan kualitas hidup pasien COVID-19 dengan comorbid diabetes melitus dan hipertensi dengan hasil uji statistik $\rho$ Value sebesar 0,001 $(<0,05)$. Pasien penyakit kronis yang terinfeksi COVID19 akan mempengaruhi kondisi kesehatan dan berdampak pada rendahnya kualitas hidup pasien penyakit kronis.

Pasien COVID-19 dengan DM cenderung mendapatkan perawatan ICU dan ventilasi mekanis invasif akibat memiliki respons inflamasi sangat berat (Roncon et al., 2020). Selain itu, pasien COVID-19 dengan diabetes memiliki prognosis yang buruk sehingga harapan hidup pasien COVID-19 dengan diabetes lebih pendek daripada yang tidak memiliki diabetes. Hal ini terjadi karena COVID-19 menyebabkan disfungsi paru-paru dan inflamasi yang berat. Port entry virus ini adalah glikoprotein permukaan khusus pada ACE2, yaitu - spikell. ACE2 melimpah di sel alveolar tipe II paru-paru. Jika jumlah ACE2 pada pasien COVID-19 berlebih, tingkat keparahan penyakit yang diderita pasien juga meningkat, seperti dapat menyebabkan ARDS, kerusakan hati, jantung, ginjal, sampai menyebabkan kematian (Sasidharan et al., 2021). Pasien COVID-19 dengan diabetes cenderung dua kali lebih berisiko untuk menderita gejala COVID-19 yang berat dan dua kali lipat lebih berisiko meninggal akibat gejala tersebut (Kumar et al., 2020).

Pasien COVID-19 dengan diabetes harus terus mengonsumsi obat-obatan yang sudah diberikan. Untuk pasien dengan gejala COVID-19 ringan, regimen obat-obatan terdahulu harus di evaluasi dan diikuti sesuai petunjuk. Untuk gejala biasa, pasien dapat menggunakan injeksi insulin subkutan, seperti regimen insulin basal /kerja-cepat prandial atau insulin premixed. Untuk pasien dengan gejala berat, dibutuhkan terapi insulin intravena (Burhan et al., 2020).

Risiko komplikasi pada COVID-19 akibat diabetes melitus cenderung tinggi, sehingga risiko terjadinya komplikasi pada COVID-19 akibat diabetes melitus juga tinggi yang akhirnya dapat memperpendek harapan hidup pasien (Huang et al., 2020). Pasien COVID-19 dengan diabetes melitus cenderung mendapatkan perawatan ICU dan ventilasi mekanis invasif akibat memiliki respons inflamasi sangat berat (Roncon et al., 2020). Selain itu, pasien COVID-19 dengan diabetes melitus memiliki prognosis yang buruk sehingga harapan hidup pasien COVID-19 dengan diabetes melitus lebih pendek daripada yang tidak memiliki diabetes melitus. Hal ini terjadi karena COVID-19 menyebabkan disfungsi paru-paru dan inflamasi yang berat. Pasien COVID-19 dengan diabetes melitus cenderung dua kali lebih berisiko untuk menderita gejala COVID-19 
yang berat dan dua kali lipat lebih berisiko meninggal akibat gejala tersebut (Kumar et al., 2020).

Pasien penyakit kronis yang terinfeksi COVID-19 akan mempengaruhi kondisi kesehatan dan berdampak pada rendahnya kualitas hidup pasien penyakit kronis. Menurut penelitian Nguyen et al., (2021) pasien dengan penyakit kronis merupakan populasi rentan dengan kualitas hidup yang rendah selama pandemi COVID-19. Penelitian lainnya dilakukan oleh Ping et al., (2020) menyatakan bahwa responden dengan tiga atau lebih penyakit kronis memiliki kualitas hidup yang lebih rendah dibandingkan responden lainnya.

\section{SIMPULAN}

Ada perbedaan kualitas hidup pasien COVID-19 dengan comorbid diabetes melitus dan hipertensi.

\section{SARAN}

Terapi yang sesuai dan komprehensif akan meningkatkan kualitas hidup pasien. Strategi pengobatan yang berfokus pada anti inflamasi sebagai pengobatan COVID19 dan menjaga respons imun pasien tetap seimbang menjadi pengobatan terbaik dalam mengeliminasi COVID-19. Pasien COVID-19 dengan diabetes harus tetap melanjutkan pengobatan sesuai dengan regimen yang ditetapkan.

\section{DAFTAR PUSTAKA}

Andri, J., Padila, P., \& Arifin, N. A. W. (2021). Tingkat Kecemasan Pasien Kardiovaskuler pada Masa Pandemi COVID-19. Journal of Telenursing (JOTING), 3(1), 382-389. https://journal.ipm2kpe.or.id/index.php/JOTING/article/view/2167

Burhan, E., Syam, A. F., Rahyussalim, A. J., Prasenohadi, P., Wulung, N. G. L., Susanto, A. D., Sajinadiyasa, I. G. K., Puspitorini, D., Lestari, D., Widyahening, I. S., Setiawaty, V., Ocviyanti, D., Putri, K. Q., Guntara, A., Rianda, D., Shankar, A. H., \& Agustina, R. (2020). The Emergence of COVID-19 in Indonesia: Analysis of Predictors of Infection and Mortality Using Independent and Clustered Data Approaches. Medrxiv, 2020.07.10.20147942. http://medrxiv.org/content/early/2020/07/11/2020.07.10.20147942.abstract

Guan, W., Liang, W., Zhao, Y., Liang, H., Chen, Z., Li, Y., Liu, X., Chen, R., Tang, C., Wang, T., Ou, C., Li, L., Chen, P., Sang, L., Wang, W., Li, J., Li, C., Ou, L., Cheng, B., \& He, J. (2020). Comorbidity and Its Impact on 1590 Patients with COVID-19 in China: A Nationwide Analysis. European Respiratory Journal, 55(5), 2000547. https://doi.org/10.1183/13993003.00547-2020.Supp1

Guan, W., Ni, Z., Hu, Y., Liang, W., Ou, C., He, J., Liu, L., Shan, H., Lei, C., Hui, D. S. C., Du, B., Li, L., Zeng, G., Yuen, K.-Y., Chen, R., Tang, C., Wang, T., Chen, P., Xiang, J., \& Zhong, N. (2020). Clinical Characteristics of Coronavirus Disease 2019 in China. New England Journal of Medicine, 382(18), 1708-1720. https://doi.org/10.1056/nejmoa2002032

Huang, C., Wang, Y., Li, X., Ren, L., Zhao, J., Hu, Y., Zhang, L., Fan, G., Xu, J., Gu, X., Cheng, Z., Yu, T., Xia, J., Wei, Y., Wu, W., Xie, X., Yin, W., Li, H., Liu, M., \& Cao, B. (2020). Clinical Features of Patients Infected with 2019 Novel Coronavirus in Wuhan, China. The Lancet, 395(10223), 497-506. https://doi.org/10.1016/S0140-6736(20)30183-5 
Kemenkes, R. (2020). Artikel 13,2 Persen Pasien COVID-19 yang Meninggal Memiliki Penyakit Hipertensi. Https://www.kemkes.go.id

KPCPEN. (2020). Peta Sebaran. Satuan Tugas Penanganan COVID-19. KCPEN

Kumar, A., Arora, A., Sharma, P., Anikhindi, S. A., Bansal, N., Singla, V., Khare, S., \& Srivastava, A. (2020). Is Diabetes Mellitus Associated with Mortality and Severity of COVID-19? A Meta-Analysis. Diabetes and Metabolic Syndrome: Clinical Research and Reviews, 14(4), 535-545. https://doi.org/10.1016/j.dsx.2020.04.044

Nguyen, Q., Van, C., D. A., \& Nghiem, S. H. (2021). Spread of COVID-19 and Policy Responses in Vietnam: An Overview. International Journal of Infectious Diseases, 103, 157-161. https://doi.org/10.1016/j.ijid.2020.11.154

Padila, P., Andri, J., Sartika, A., Andrianto, M, B., \& Harsismanto, J. (2021). Pengalaman Single Parents dalam Merawat Anak yang Terkonfirmasi Positif COVID-19. Jurnal Kesmas Asclepius, 3(2), 41-48. https:// doi.org/10.31539/ jka.v3i2. 2896

Padila, P., Panzilion, P., Andri, J., Nurhayati, N., \& Harsismanto, J. (2021). Pengalaman Ibu Usia Remaja Melahirkan Anak di Masa Pandemi COVID-19. Journal of Telenursing (JOTING), 3(1), 63-72. https://doi.org/10.31539/joting.v3i1.2075

Ping, W., Zheng, J., Niu, X., Guo, C., Zhang, J., Yang, H., \& Shi, Y. (2020). Evaluation of Health-Related Quality of Life Using Eq-5d in China During the COVID-19 Pandemic. PLoS ONE, 15(6). https://doi.org/10.1371/journal.pone.0234850

Roncon, L., Zuin, M., Rigatelli, G., \& Zuliani, G. (2020). Diabetic Patients with COVID-19 Infection are at Higher Risk of ICU Admission and Poor Short-Term $\begin{array}{llll}\text { Outcome. Journal of Clinical } & \end{array}$ https://doi.org/10.1016/j.jcv.2020.104354

Sasidharan, S., Singh, V., Singh, J., Madan, G. S., Dhillon, H. S., Dash, P. K., Shibu, B., \& Dhillon, G. K. (2021). COVID-19 ARDS: A Multispecialty Assessment of Challenges in Care, Review of Research, and Recommendations. In Journal of Anaesthesiology Clinical Pharmacology, 37(2), 179-196). https://doi.org/10.4103/joacp.JOACP_14_21

Schwartz, M. R., \& Oppold, P. (2021). The Impact of Assistive Technologies on Quality of Life and Psychosocial Well-Being. In Research Anthology on Physical and Intellectual Disabilities in an Inclusive Society, 713-725. https://doi.org/10.4018/978-1-6684-3542-7.ch038

Tignanelli, C. J., Ingraham, N. E., Sparks, M. A., Reilkoff, R., Bezdicek, T., Benson, B., Schacker, T., Chipman, J. G., \& Puskarich, M. A. (2020). Antihypertensive Drugs and Risk of COVID-19? In The Lancet Respiratory Medicine, 8(5), e30-e31. https://doi.org/10.1016/S2213-2600(20)30153-3

WHO. (2019). Coronavirus Disease 2019 (COVID-19)

WHO. (2020). Rational Use Of Personal Protective Equipment For Coronavirus Disease 2019 (COVID-19). WHO Interim Guidance, 2019(February), 1-7. https://apps.who.int/iris/bitstream/handle/10665/331215/WHO-2019-nCovIPCPPE_use-2020.1-eng.pdf

WHO. (2021). WHO Coronavirus (COVID-19) Dashboard Global Situation. WHO, https://COVID19.who.int/. https://www.who.int/COVID-19

Willim, H. A., Ketaren, I., \& Supit, A. I. (2020). Dampak Coronavirus Disease 2019 terhadap Sistem Kardiovaskular. E-CliniC, 8(2), 237-245. https://doi.org/10.35790/ecl.v8i2.30540 